\title{
Perspectives of energetic exports of Russia in terms of development of the renewable energy sources
}

\author{
Elena Andreeva ${ }^{1, *}$, Alla Golovina ${ }^{1}$, and Victoria Zakharova $^{2}$ \\ ${ }^{1}$ Ural State University of Economics, 8 Marta str. 62/45, 620144 Yekaterinburg, Russian Federation \\ ${ }^{2}$ Ural Branch of Russian academy of sciences, Moskovskaya str. 29, 620014 Ekaterinburg, Russian \\ Federation
}

\begin{abstract}
The changes in the sphere of the main energy sources in the world and in individual countries were highlighted; the prospects for Russian energy carriers in the global hydrocarbon market were identified. The demand for an energy carrier whose use in Germany is planned to be discontinued (coal) and the demand and competition for natural gas Russian energy carrier that remains competitive in the conditions of "green" energy were analyzed. The Russian opportunity to save the energy supply market on the background of the new energy order are considered.
\end{abstract}

\section{Introduction}

The most of researches in recent years have been focused on the active development of renewable energy sources. As well as wind power, hydropower and biofuels, there are number of potential energy sources under the study: methyl hydrate, nuclear fusion, thorium energy sources, traveling wave reactor. Despite the fact that, in general, the massive use of renewable energy sources is just in the development stage, but currently new energy sources (including shale gas production) do not allow oil-exporting countries to raise prices, limiting their income [Akacem et al, 2020: 88-89]. Those countries that pass environmental legislation and are poorly supplied with fossil fuels practice subsidizing prices for renewable energy sources and buying rights to exploit foreign fuel deposits [Ravetti et al, 2020: 115-116]. A tendency has been noted that passing environmental legislation in terms of renewable energy sources slows down the import of fuel by countries [Nunez-Rocha et al, 2019: 325-326]. Concerning this tendency it is very important for Russia as one of the major energy carrier exporter to improve its technology of deep fuel, particularly oil, reforming. Regarding traditional fuels, it is noted that new efficient technologies that reduce carbon dioxide emissions appear (HELE). Thus, in the coal industry appeared technologies such as integrated gasification combined cycle, carbon capture, underground gasification and coal liquefaction [Bhattacharyya, 2019: 695-696]. Collision between environmental and economic determinants creates the uncertainty about the future of the energy trade. Meanwhile, the study of the genotype of industrial development of territories formation shows that in the case of neo-industrial development

*Corresponding author: elenandr@mail.ru 
the economic past of the territory will be reflected in its future [Andreeva et al, 2017: 740]. Therefore, energy-resource countries (including Russia) forced to overbuild their planned future on the traditional economic specificity.

It is evident, energy carriers still remain one of the most important component of Russian exports. But the question is needed to be asked: however, what are the prospects for Russian energy carriers in the global hydrocarbon market, taking into account the development of alternative energy.

\section{Materials and methods}

It would be useful to analyze the structure demand for the least and most environmentally friendly energy source.

At the first step, we will analyze the demand for an energy carrier whose use in Germany is planned to be discontinued (coal). It is believed that the demand for energy imports in the world will remain. In case of developed economies mainly reduce energy consumption, developing economies, on the contrary, increase it. Globally, the forecasted primary energy consumption will grow on $17-27 \%$ by 2040 [Global and Russian Energy Outlook 2019, 2019: 57]. At the same time according to forecasts the share of coal in the world primary energy consumption will decrease, but continue to remain significant: it is expected to decline from $28 \%$ (2015) to $19 \%$ (2040) in the case of energy transition to renewable energy. In the case of a conservative scenario, the share of coal in 2040 will be 23\% [Global and Russian Energy Outlook 2019, 2019: 61] In general, the weight of coalfired energy generation will decrease from $38 \%$ in 2017 to $20-25 \%$ in 2040 [Khokhlov et al, 2019: 4-5]. Coal consumption in Africa and the Middle East will not peak until 2040. And in the case of a conservative scenario, it will also not occur in developing countries in Asia and South America [Global and Russian Energy Outlook 2019, 2019: 61]. Therefore, the absolute values of the use of coal will remain: developing Asian countries will be significantly ahead of the absolute volumes of its use in electricity generation. Even in the case of an energy transition, these volumes will amount about $6000 \mathrm{TW}-\mathrm{h}$ or about $1 / 3$ of all power sources of these countries in 2040 [Global and Russian Energy Outlook 2019, 2019: 65].

This is the fact that in the developing economies of Asia and Africa, the more important factor is not the environmental friendliness of the energy resource, but its cost, and coal has an advantage in this aspect due to economic reasons. Also the status of coal remains stable on the global scale. Large economies (Chinese, US and Indian) together accumulate 7/10 of the world's coal generation. At the same time, China, India, Poland (EU member) and South Africa generate over $2 / 3$ of their electricity from coal (2017). The stable status of coal remains, among other things, due to the 2011 Fukushima accident [Khokhlov et al, 2019: 9]. An example of Russian opportunities in the growing and remaining sales markets is plans to start operation of a new large Arctic coal deposit (Syradayskoe deposit), with export potential to the Netherlands, India, China, Korea, Japan (early indications say that by the 202410 ice-class ships will be needed). However, it is estimated that under the influence of environmental determinants coal generation will have to strive to increase efficiency (through the development of cogeneration technologies) and environmental friendliness (through modernization and released material entrapment) of clean coal technologies [Khokhlov et al, 2019: 4-6].

Regarding the geographical reorientation of exports, it can be noted that, starting with the strengthening of protectionism in international trade (since the international sanctions of the 2010s), Russia is forced to analyze the possibilities of reorienting export flows from developed to developing countries. China is an important trading partner. In the context of coal exports, it can be noted that in December 2020, China (being for Australia the country 
on the second position in the coal export rating) stopped imports of Australian coal. This case shows that theoretically there are opportunities to find demand for Russian coal if Germany refuses coal. However, the possibilities of the railroad need additional research.

At the second step, we will analyze the demand and competition for natural gas Russian energy carrier that remains competitive in the conditions of "green" energy. Of all non-renewable mineral fuels, only natural gas is projected to increase its share in global energy consumption by 2040: from $22 \%$ to $25-27 \%$, including in Europe - by 20-40 billion cubic meters; in developing Asian countries except China and India - by 200 billion cubic meters; in China - by 4,000 billion cubic meters [Global and Russian Energy Outlook 2019, 2019: 104]. In countries with highly developed environmental policy, natural gas is given priority in power generation. For example, the count of terminals for receiving liquefied natural gas (LNG) in Europe has been increased. At the same time, natural gas production in Europe will decrease by one hundred billion cubic meters by 2040, while in Russia it will increase by two hundred billion cubic meters. But a comparable increase is expected in the United States and Canada, China, the Middle East, and Africa. Also It is expected an increasing use of non-traditional (new) technology in the production of gas: biogas production, gasification of coal, production of coalbed methane, shale gas, the development of new natural gas fields, natural gas liquefaction [Global and Russian Energy Outlook 2019, 2019: 107-108, 110]. This forces all natural gas suppliers to monitor the competitiveness of their production and transportation technologies.

\section{Results and discussion}

In 2018 , the German import dependence of coal was $88.4 \%$, lignite $-70.1 \%$, oil $-97.2 \%$, gas $-96.2 \%$, nuclear energy - 100\%. In 2019, lignite and hard coal accounted for $20 \%$ and $9 \%$ respectively in the energy balance of Germany respectively; atomic energy $-14 \%$. In total, coal and nuclear energy account for $43 \%$ of the country's energy balance. Therefore, it can be assumed that if Germany refuses these energy sources, there will a significant gap in its energy market occur. However, according to estimates, Germany's intentions are to replace this gap with renewable energy sources, so that the demand for natural gas will grow by only about $1 / 10$ of the existing Russian natural gas exports to Germany, and even this increase can be offset by energy efficient policies at the beginning of the 2030s. Although conditions for the growth of the foreign natural gas demand may arise due to the exhaustion of gas fields operated in Germany.

The volume of Russian exports of mineral fuel to Germany remains significant and show grows: $\$ 10.6$ billion in 2004, \$15.1 billion in 2009, \$ 23.4 billion in 2019 (Figure 1).

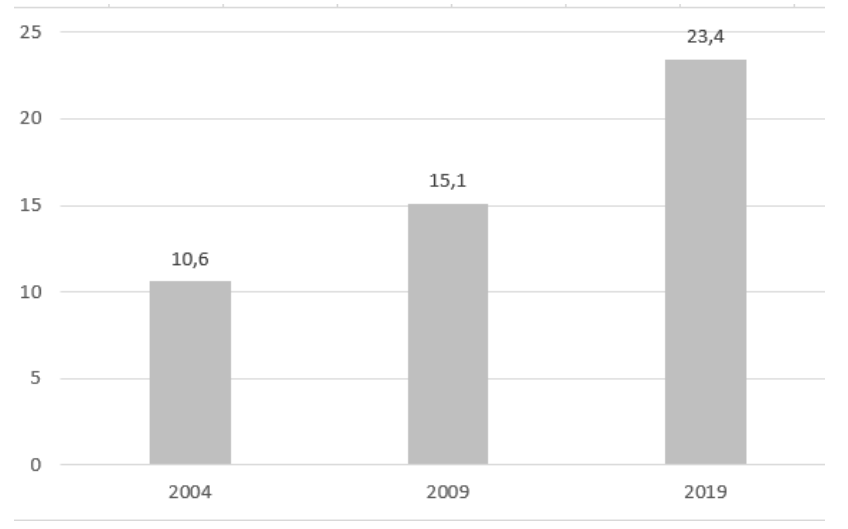

Fig. 3. The volume of Russian exports of mineral fuel to Germany 
Germany's share in gross Russian mineral fuel exports is relatively stable (appr. 1/10) despite significant fluctuations in its absolute volume (from 100 to 346 billion dollars). It indicates that Russia is an important energy supplier for Germany (Table 1).

Table 1. Share of Russian fuel exports to Germany,\%

\begin{tabular}{|c|c|c|c|}
\hline Year & Mineral fuel & Coal $^{1}$ & Gas hydrocarbons $^{2}$ \\
\hline 2004 & 10,7 & 4,6 & 17,3 \\
\hline 2009 & 7,9 & 1,5 & 15,6 \\
\hline 2014 & 8,7 & 2,9 & 19,2 \\
\hline 2019 & 8,9 & 8,9 & 20,7 \\
\hline
\end{tabular}

Hard-coal. Natural gas in gaseous state

Source: Customs statistics of foreign trade. URL: stat.customs.ru/documents (accessed 20.02.2021).

Germany's share in the Russian export of coal is low (2.9\% in 2014, $1.5 \%$ in 2009) although it reached $8.9 \%$ in 2019 . However, the absolute volume of coal was growing: from 108 in 2009 to 337 million dollars in 2014. It also demonstrates the importance of Russia as an energy supplier for a number of developed economies.

However, for gaseous hydrocarbons, Germany takes significantly more share of Russian export shipments $15-20 \%$ ( $\$ 6-12$ billion). This corresponds to the German environmental policy: the natural gas is considered to be more environmentally friendly than coal.

Even in case if natural gas will remain in demand for developed economies, the leading importers of Russian fuel, the pressure of competition is significant. The liquefied gas supply is developing in the whole world, and competition between gas pipelines remains. This can be seen in particular because that the Russian energy export to Germany is sensitive to shocks. Therefore, for 9 months 2020 (compared to the same period in 2019), due to the pandemic COVID19, Russian exports to Germany significantly decreased. And it is noteworthy that the decrease in absolute values primarily affected the resource positions: oil and gas production ( -5.5 billion dollars), coke chemistry and oil refining ( -1.3 billion dollars), metallurgy and coal mining (-0,7 billion dollars). In addition, due to the depletion of gas reserves in the developed fields, Russia is forced to start developing new ones placed in more difficult conditions.

This leads to the improving technologies of the Russian fuel and energy, transport and logistics complex: technologies for the production of natural gas, its liquefaction and logistics of its delivery, taking into account hard-to-reach areas and harsh climatic conditions. For example, gas and LNG production in the Yamal arctic region has began in 2017.

The transport and logistics infrastructure of Russian natural gas export was also being improved. Construction of the "Nord Stream 2" (system of natural gas pipelines to Europe) required large investment, production, technological resources, and a huge volume of legal work of international negotiation. The technological and environmental argument of the project is that there are estimates according to which Germany's acceptance of Russian pipeline gas is more environmentally friendly than LNG from the United States. These estimates are related to the peculiarities of receiving tankers, the danger of LNG terminals due to the proximity to a chemical plant, the environmental characteristics of shale gas production technology in the United States. This project also includes Russian-German investment cooperation: among its investors, in addition to Gazprom, there are also German companies Uniper and Wintershall. 


\section{Conclusions}

Thus, the Russian fuel and energy complex and its export-oriented segment are improving export strategies in connection with the introduction of renewable energy sources in Germany. More attention is paid to forecasting energy demand and analyzing competition between suppliers.

Germany consistently buys from $1 / 6$ to $1 / 5$ of Russian natural gas. By introducing environmental standards, restructuring the economy of coal-mining regions, the country still, at least in the short term, enhances the likelihood of demand for energy imports, which will contribute to ensuring its green energy regime. If Germany refuses from coal and nuclear power generation, which occupy a significant place in its energy balance, the demand for natural gas should grow. With the growing demand for hydrogen energy in Germany, Russia can transform its supply of natural gas into a supply of hydrogen. The socalled "Hydrogen Turn" is forcing the leading Russian suppliers of energy resources to test hydrogen production technologies, to monitor and analyze the possibilities of cooperation and localization of advanced technologies in Russia. In these conditions, Russia gets the opportunity to save the energy supply market on the background of the new energy order.

\section{Acknowledgements}

The article was prepared by financial support of RFBR (Russian Foundation for Basic Research), project number 20-010-00806-A.

\section{References}

1. M. Akacem, D.D. Miller, J.L. Faulkner, Oil, Institutions and Sustainability in MENA, $235(2020)$

2. E.L. Andreeva, D.A. Karkh, Yu.G. Myslyakova, Ekonomika regiona, 13(3), 732 (2018)

3. V.V. Belov, Sovremennaya Evropa, 5, 65 (2020)

4. S.C. Bhattacharyya, Energy Economics, 683 (2019)

5. E. Dahlbeck, S. Gärtner, Just transition for regions and generations: Experiences from structural change in the Ruhr area, 66 (2019)

6. A. Khokhlov, Yu. Mel'nikov, Coal generation: new challenges and opportunities, 87 (2019)

7. T. Nunez-Rocha, C. Turcu, Comparative Economic Studies, 61(2), 302 (2019)

8. Global and Russian Energy Outlook 2019, 210 (2019)

9. C. Ravetti, T. Theoduloz, G. Valacchi, Environmental and Resource Economics, 77(1), 95 (2020)

10. A.V. Streltsov, G.I. Yakovlev, Technological and Economic Justification of Development Tendencies of the Russian Petroleum Refining Industry, 393 (2019) 